\title{
Issues Involving Corporate Transparency in the Saudi Capital Market
}

\author{
Khalid Saad Al-habshan ${ }^{1}$ \\ ${ }^{1}$ School of Law, Brunel University, UK \\ Correspondence: Khalid Saad Al-habshan, School of Law, Brunel University, UK. E-mail: \\ habshan_33@hotmail.com
}

Received: May 5, 2017 Accepted: June 26, 2017 Online Published: October 30, 2017

doi:10.5539/par.v6n2p21

URL: http://dx.doi.org/10.5539/par.v6n2p21

\section{Overview}

In this article, disclosure and transparency issues in Saudi Arabia are discussed as they pertain to the Saudi capital market. Disclosure provisions in the CML and problems that result from inadequate disclosure are examined. Insider dealing, price manipulation and possible reforms of Saudi law are addressed. Finally, a brief account of voluntary disclosure and its impact on the mandatory disclosure of financial information by SSE-listed companies is given, as well as the WB's findings on Saudi companies' disclosure practices.

\section{Saudi Arabia's Approach to Disclosure and Transparency}

From the earlier discussion of general corporate governance in Saudi Arabia, there appears to be in place a regulatory framework that sets the conditions for the adoption of effective corporate governance. However, this framework has shortcomings. The CL and the CGR, the two legal frameworks that establish corporate governance requirements for business corporations, are sometimes complementary and consistent but, in other cases, are contradictory or inconsistent and interfere with each other.

Transparency and the disclosure of information are determinants of development and economic growth and without them economic progress cannot be sustained. The robustness of activity in a market economy depends to a great extent on complete, timely and accurate information which determines resource allocation, improves the efficiency of market activity and increases production, which drives the economy. The preceding chapters, particularly the discussion of scandals and disclosure, demonstrated that SSE listed companies still fall short of the standard of transparency desirable for an efficient market, in part because Saudi Arabia is an emerging economy and Saudi corporate culture is still assimilating the corporate governance culture. The behaviours of individuals involved, such as board members, executives and investors, are conditioned by the customary Saudi social relations and have yet to be adjusted to the constraints of abiding by international standards that are different to accustomed behaviour.

\section{Disclosure Provisions in the Capital Market Law}

The CMA Listing Rules aim to protect investors and contribute to the development of the capital market. They are more specific and detailed than the earlier rules under the Ministry of Commerce, which were ambiguous, restricted market access and were time consuming. ${ }^{1}$ The CML LR describe the information disclosure required for companies to list their securities in the stock market. The law also orders listed companies to abide by periodic reporting and disclosure requirements.

The CML disclosure rules meet the international standards set by the IOSCO, Basel Committee on Banking Supervision and the London Stock Exchange (LSE). The comparability of the Saudi and London stock exchanges is qualified by the innate structural differences between an emerging market only a few decades old and a developed, mature market. Emerging markets are prone to problems not present in developed markets, such as a lack of transparency and risk management, weak market infrastructure and investor misbehaviour. ${ }^{2}$

Another problem is the lack of predictability in the immediate time ${ }^{3}$ - for instance, when there are insufficient counter buy and sell orders in the market then the prices of the particular stock become volatile. This major problem enables unscrupulous traders to work together to employ manipulative techniques to 'paint the tape'.

\footnotetext{
${ }^{1}$ Abdulrahman Y Baamir, 'Issues of Transparency and Disclosure in the Saudi Stock Market' (2008) 22 Arab Law Quarterly 63.

2 International Monetary Fund, Global Financial stability Report (IMF 2003) Chapter 3.

${ }^{3}$ Identified by the OECD as a major weakness in Challenges for Reform of Financial Markets in MENA Countries (OECD 2006).
} 
This is a form of market manipulation where a group of market players conspires to influence the market price of a security by buying and selling it among themselves. This creates the impression that there is significant trading activity in the stock and so they are able to take advantage of less savvy investors. ${ }^{4}$

Another characteristic of the Saudi market is the noticeably few listed companies, numbering only 113 compared to the average of 300 to 350 in other emerging markets. Consequently, the SSE is a relatively illiquid market, focusing on a small number of stocks, with trading activity concentrated on a small number of dealers. Ideally, a stock exchange has larger firms, but in Saudi Arabia the largest 20 or so companies are not listed because they are family or state owned and have no public ownership. ${ }^{5}$

The LR can be easily understood by investors who do not usually seek expert advice in regards to investment decisions. The language used is clear although the rules are nearly identical to those of LSE.

The concepts of disclosure and transparency are very important in the business world and financial market. When applied, the concepts ensure that information is shared publicly and the financial system is controlled. The Basel Committee on Banking Supervision and the IOSCO Technical Committee strongly recommended the adoption of such concepts by security companies and banks. They provide a logical, clear basis for all investor decision making and market discipline, which helps clarify firms' management strategies and expose their risks. Companies that practice transparency and disclosure can be evaluated easily and protect themselves from suspicions in the case of financial crises. ${ }^{6}$ The two Committees urge firms to provide clear summaries of their activities, including quality and quantity. In addition, all risks — credit, market and liquidity — should be declared to the public, and how these factors affect them should explained. According to the Committees' recommendations, firms should detail their policies in dealing with the expected and existing risks.

For better financial comprehension, it is also important to separate trading and non-trading activities. Compared with developed countries, the Saudi CML represents a good attempt to cope with the international standards regarding disclosure of information. The CML includes provisions addressing the prohibition of market manipulation, security issuers, members of management and majority shareholders.

Sufficient, adequate information has to be disclosed in order to create a full picture of investment affairs, including the issuer's financial position, securities to be issued, rights and privileges. If the information is inaccurate, the issuer or person responsible must compensate the affected investors. All these measures will help create a solid investment environment in the Saudi capital market.

Some articles in the Saudi LR mandate disclosing information about securities before issuing them. Such information has to be sufficient for an investor to assess the financial position, activities and related aspects of the company and help make decisions about it. ${ }^{7}$ This information should also convey all aspects of the rights attached to the shares (e.g. voting, dividends, repurchase).

Moreover, the financial status of the company or the issuer and their administration body has to be clear and unambiguous. ${ }^{8}$ In the FSA rules, Article 2.1.1 outlines the content of the necessary information, while Annex I includes the minimum disclosure requirement for shares' registration documents, similar to the Saudi rules. ${ }^{9}$

Through August 2006, the CMA has published 16 prospectuses which fulfilled the information requirements in annexes 4 and 5 of the LR. ${ }^{10}$ However, the new regulations have not changed the LR's restriction of information access to only well-established corporations. In contrast, the FSA accepted 25 prospectuses in the second half of July. ${ }^{11}$ In both cases, the authority must approve the prospectus under SSE rules before publication.

The CMA takes other appropriate steps, such as asking the applicant to appear before the authority for questioning, providing further information or undertaking relevant studies. This person has to be aware of all related matters that might be discussed when appearing before the authority in order to give adequate answers.

\footnotetext{
${ }^{4}$ Baamir (n 382) 65.

5 ibid 66.

6 'Recommendations for Public Disclosure of Trading and Derivative Activities' (Consultative paper issued jointly by the Basel Committee on Banking Supervision and the Technical Committee of the International Organization of Securities Commission, 1999) $<$ http://www.bis.org/publ/bcbs60.pdf> accessed 25 March 2014.

7 The Listing Rules (LR) were pursuant to CMA Board Resolution No 3-11-2004, dated 4 October 2004 and amended by a Resolution of Capital Market Authority Board No 2-128-2006, dated 22 January 2006, Article 21.

8 ibid Annex 4.

${ }^{9}$ FSA, 'Article 2.1.1, General Content of the Prospectus Rules' (FSA Handbook, March 2013).

${ }^{10}$ Additional information must be disclosed in some sectors, such as insurance and mining.

${ }^{11}$ FSA, The Listing Review and Prospectus Directive, Stock Market Regulation (FSA 2005).
} 
According to the SSE rules, the issue must make disclosure to the authority if the existing securities will increase by less than $10 \%$ because of the issue or if the shares are issued due to a bonus to the listed shareholders of the company. However, a prospectus is not required if the issuer's employees are granted shares or the issue is due to converting debts. ${ }^{12}$ If no increase in the securities is expected, a prospectus is not required, following Section 1.2 of the FSA Prospectus Rules. This also applies in cases when an employer grants shares to employees.

According to the Saudi rules, the issuer must publish a prospectus fourteen days before posting it online and releasing it in hard copy offered free of charge to the public. ${ }^{13}$ In contrast, Article 3.2.2 ${ }^{14}$ of the UK rules adopts the principle of reasonableness, requiring the prospectus to be published six days before the IPO. According to Article 3.2.3, if a major change occurs in relation to the prospectus or the documents after approval, a supplement is needed. ${ }^{15}$ The FSA also addresses inaccurate information and mistakes mentioned in the approved prospectus.

The authority can demand a higher level of disclosure by asking for more information or requiring other obligations in sectors such as insurance. ${ }^{16}$ Article 26 of the LR favours listed companies regarding disclosure rules:

In the opinion of any issuer, disclosure of any matter required by these Rules would be unduly detrimental to the issuer, and omission is not likely to mislead investors with regard to facts and circumstances, essential knowledge for the assessment of the securities in question, the issuer may apply for a waiver from the relevant requirement. ${ }^{17}$

The rules of the LSE also allow some exceptions to the disclosure of certain business activities:

In long-term contracts, where disclosure would be seriously detrimental to the applicant or against the public interest, a waiver from the requirement of making a material contract publicly available can be granted subject to the UKLA discretion. The waiver may be granted only for specific parts of a contract and, generally, will not be granted merely on the grounds of commercial sensitivity. ${ }^{18}$

The SSE rules do not offer a justification for not disclosing information. The FSA does not consider the sensitivity of business information or exempt parts of the transaction that may affect the issuer. ${ }^{19}$ The purpose of imposing further obligations is to guarantee the continuous release of information to treat market participants equally. ${ }^{20}$ The LR mention such obligations, especially with regard to significant developments and the necessity to make them public.

In addition, the CMA and shareholders should be informed about interim accounts approved by the issuer's board of directors, as well as the annual accounts that must be prepared according to SOCPA criteria. ${ }^{21}$ If a firm fails to submit such reports to the authority, it could be subject to disciplinary action, such as a fine or suspension of its securities. ${ }^{22}$

In addition, the authority should be informed of investors who own $5 \%$ or more of voting shares in a firm at the end of the trading day, as well as any increase or decrease of $1 \%$ or more. ${ }^{23}$ The aim of disclosure of interest is to draw the attention of other shareholders to the new shareholder or those whose shares have increased. Such shifts in shareholding can result in significant changes in the aspects of the firm, such as its articles of

\footnotetext{
${ }^{12}$ The market for debt instrument has not been developed yet; however, the introduction of sukuk, or Islamic bonds, saw reasonable success.

${ }^{13}$ LR (n 388) Article 22.

${ }^{14}$ The prospectus must be filed and made available to the public as soon as practicable, at a reasonable time in advance of and at the latest at the beginning of the offer or the admission to trading of the transferable securities involved.

${ }^{15}$ LR (n 388) Article 24.

16 ibid Article 26; 2.1.4.

17 ibid Article 26.

${ }^{18}$ Linklaters \& Alliance, The Automatic Choice for LES Listing (Linklaters \& Alliance 2002).

${ }^{19}$ LR (n 388) Article 18.

${ }^{20}$ FSA, 'Admission and Disclosure Standards' (FSA, July 2005).

${ }^{21}$ LR (n 388) Article 25; SOCPA (n 153).

${ }^{22}$ In an announcement on 20 April 2004, the CMA warned seven companies because of delays in the submission of their interim account reports and suspended trading in the securities of one company later that week. CMA, 'Chapter Seven Disclosure Article Forty Two CML' $<$ www.cma.gov.sa> accessed 27 March 2014.

${ }^{23}$ LR (n 388) Article 30.
} 
association or board of directors. ${ }^{24}$

Furthermore, Almelhim argues that the disclosure of interest will make the shareholders aware of firms' financial status and help protect their interests. The authority requires that issuers notify it regarding their capital and changes, including those to holdings or ownership of more than $5 \%$ of the listed securities. ${ }^{25}$ Moreover, all decisions related to company activities, such as payment or non-payment of dividends, purchases, draws, redemptions, and changes to the rights attached to any listed securities, must be reported to the CMA without delay. ${ }^{26}$ In comparison with the UK, the FSA requires that the information be published on time to help the market function properly. However, disclosure of information to the SSE has to follow certain criteria, including continuous obligations. Any activity that might influence the company shareholders must be reported, and such measures have to be in compliance with International Financial Reporting Standards, as stated by the LR. ${ }^{27}$

\section{Disclosure and Transparency in Saudi Arabia}

In a discussion of corporate governance, it can be argued that disclosure and transparency mean that firms release to the public their financial status, activities, decisions and any related company information that concerns investors. ${ }^{28}$ This definition lends these concepts significant importance in capital markets in general and in corporate governance specifically, whether local or global. ${ }^{29}$

The first OECD Principle of Corporate Governance is:

The corporate governance framework should promote transparent and efficient markets, be consistent with the rule of law and clearly articulate the division of responsibilities among different supervisory, regulatory and enforcement authorities. ${ }^{30}$

The application of disclosure as required by corporate governance results in making public information that helps investors, shareholders and all other parties interested in a company in order for them to make their decisions regarding their investments. Such information must accurately reflect the company's real situation in the capital market in order to provide a comprehensive picture for all those interested. Disclosure includes sharing the real financial status of the company in the market with all relevant parties, which makes clear the managerial process and allows the detection of any act of fraud. ${ }^{31}$ In addition, this supports the rights and benefits of shareholders as the board of directors' behaviours are visible, and it cannot lead the company to achieve its interests at the expense of shareholders. Shareholders can decide whether to sell or buy shares in the company. ${ }^{32}$

In this context of corporate governance, the Winter Report states that:

Disclosure can be a powerful regulatory tool; it creates an incentive to comply with best practice, and allows members and third parties to take necessary actions. Disclosure requirements can be more efficient, more flexible and easier to enforce. ${ }^{33}$

The Saudi CMA emphasises the concepts of disclosure and transparency in the CGR, requiring all companies listed in the market to apply them. ${ }^{34}$ Article 9 of the CGR on disclosure in the board of directors' report declares that:

\footnotetext{
${ }^{24}$ Ahmed Almelhim, 'Comment on Kwuaiti Law No 2 of 1999 Concerning the Disclosure of Interest in Shares in the Light of Comparative Law’ (2000) 15(3) ALQ 221.

${ }^{25}$ ibid.

${ }^{26}$ LR (n 388) Article 32.

${ }^{27}$ FSA Handbook, 'Rule $12.47 \mathrm{a}$ '.

${ }^{28}$ IMF (n 59) 7.

${ }^{29}$ It is argued whether the disclosure of financial information by a corporation ought to be regulated by the CL or CML. It seems appropriate for it to be both as it shows up the inauthenticity of the division between the two laws. See Pettet, Lowry and Reisberg (n 334 ) 182.

${ }^{30}$ OECD (n 87) 17.

${ }^{31}$ Oso and Semiu (n 1) 2-16.

${ }^{32}$ Faith Kahn, 'Transparency and Accountability: Rethinking Corporate Fiduciary Law's Relevance to Corporate Disclosure' (2000) 34 GLR 512 .

${ }^{33}$ European Commission, 'Report of the High Level Group of Company Law Experts on a Modern Regulatory Framework for Company Law in Europe' (4 November 2002) 4.

${ }^{34}$ The CMA Board issued Resolution No 1-36-2008, dated 10 November 2008, making Article 9 of the CGR compulsory for all listed companies.
} 
In addition to what is required in the Listing Rules in connection with the content of the report of the board of directors, which is appended to the annual financial statements of the company, such report shall include specific disclosure requirements. ${ }^{35}$

Furthermore, other articles of the LR stipulate related requirements. ${ }^{36}$ In comparison with the rules of other

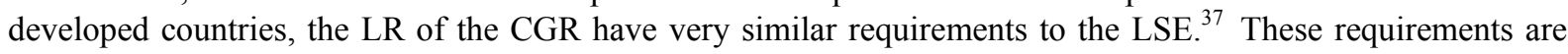
found in UK legislation: the Financial Services Authority (FSA), Disclosure and Transparency Rules, FSA Listing Rules and the UK Corporate Governance Code. ${ }^{38}$

In general, such requirements of corporate governance are almost identical in Saudi Arabia and the UK. The greatest similarities are in the rules applied to the listed corporations in both countries. Slight differences emerge in the level of development of the capital market in these countries. ${ }^{39}$

The Saudi CGR requires that corporations include the concepts of disclosure and transparency in their articles of association, including mechanisms to apply them to the board of directors and releasing information to all relevant bodies interested in the company. ${ }^{40}$ The board of directors is responsible for leading the company and its activities in order to benefit all partners in the company. This aim can be achieved through disclosure and transparency. 41

\subsection{Annual Board Report and the Importance of Disclosure and Transparency}

After the 2006 SSE crisis, it became clear that companies had ignored most disclosure and transparency requirements for annual reports, and accurate, precise information about the financial status of companies was lacking. Only a few documents, such as auditors' reports, balance sheets and profit and loss accounts, were correct. $^{42}$ The same pattern was seen during the global financial crisis (2007-2008) where no true, reliable information was shared. ${ }^{43}$

Under the CGR, companies have to disclose updated information and make it accessible to all interested parties. In addition, annual reports should pay special attention to shareholders. ${ }^{44}$ The annual board reports serve as the most reliable source of information about Saudi companies although these reports are difficult to understand. ${ }^{45}$ It seems that many shareholders are unfamiliar with the legal and financial terms used in these reports; therefore, the language should be simpler and easier to comprehend. ${ }^{46}$

As a step towards facilitating access to information and providing understandable reports, many corporations have started to use modern means of communications, such as the Internet, in order to make it easier for shareholders and interested parties to access the information they need to make investment decisions. ${ }^{47}$ Many listed companies in Saudi Arabia have used technology to present their boards' annual reports.

Providing a clear, satisfactory board annual report needs the efforts of auditors with high levels of expertise ${ }^{48}$ who can practise disclosure and transparency by disseminating significant information about the company's true financial status, as is required by corporate governance worldwide. The OECD Principles stipulate that:

\footnotetext{
35 CGR (n 8) Article 9.

36 LR (n 388).

${ }^{37}$ Riyadh Chamber of Commerce and Industry, Corporate Governance: The Definition, the Principles, and the Saudi Experience (Arabic edn, 2007) 56.

38 The UK Corporate Governance Code (Financial Reporting Council, September 2014).

39 ibid.

${ }^{40}$ CGR (n 8) Articles 4(A), 8 and 10(F).

41 Joseph Carcello, 'Government and the Common Good' (2009) 89 JBE 11.

42 Ibrahim Al Muneef, Corporate Governance Functions and Duties and Responsibilities of the Board of Director (Arabic edn, Dar Al Mouder 2006) 96

43 Susan Bartlett and Roy Chandler, 'The Private Shareholder, Corporate Governance and the Role of the Annual Report' (1999) JBL 415.

${ }^{44}$ CGR (n 8) Article 4(B). The CL (n 7) can be taken as the reference for enabling shareholders to obtain the corporation's board annual financial report and other information. Article 89 of the CL affirms that the board of directors should set the date of the annual GSM at least 30 days in advance and, for each financial year, prepare a company balance sheet, profit and loss account and report on the company's operations, financial position and proposed method for the distribution of net profits. The chairperson of the board of directors should sign these documents, and copies should be distributed to shareholders by the company headquarters at least 25 before the set date of the GSM.

45 Mamdouh Ba-Owaidan, 'The Contribution of Accounting Information to Investor Decisions in the Saudi Stock Market' (PhD thesis, University of Hull 1994) 124.

46 Braendle, Kostyuk and Apreda (n 9) 416.

47 CGR (n 8) Article 4(B).

48 Sweeney Baird, 'The Role of the Non-Executive Director in Modern Corporate Governance’ (2006) $27(3)$ CL 69.
} 
An annual report should be conducted by an independent, competent and qualified auditor in order to provide an external and objective assurance to the board and shareholders that the financial statements fairly represent the financial position and performance of the company in all material respects. ${ }^{49}$

Experienced auditors can provide good board reports which comply with the CGR provisions related to disclosure and transparency in corporate governance. ${ }^{50}$ Some scholars argue that well-known, large companies in Saudi Arabia, such as Saudi Basic Industries Corporation (SABIC) and Saudi Telecommunications Company (STC), should disclose information and make their reports available before smaller companies do as these larger businesses already have qualified, expert auditors working for them. ${ }^{51}$ Such large companies should also provide additional information through more regular supplements than small businesses. ${ }^{52}$ High-level international companies frequently present their board annual reports of their activities in a specific way, including the expected risks and profits, which lower-level companies usually cannot do. ${ }^{53}$

\subsection{Disclosure and Transparency Requirements of the Annual Board Report}

The Saudi disclosure and transparency requirements can be found in the rules of corporate governance in many countries. These concern the sharing of firm information and the production of board annual reports. In comparison with the provisions regarding disclosure and transparency in the UK, for example, the CGR emphasises disseminating company information and board annual reports to interested parties in an accessible manner and offers recommendations on how to do so in the approved manner of listings. ${ }^{54}$ The disclosure and transparency requirements for board annual reports of listed companies are as follows: ${ }^{55}$

1) A detailed description of the board's main activities;

2) The board's plans and decisions regarding the company's structure, expansion, future prospects and expected risks;

3) A statement of any material differences between the most recent and next operations;

4) An explanation of any deviation from the accounting standards espoused by the SOCPA;

5) Data about each subsidiary and its scope of business, main country of operation and assimilation;

6) An explanation of any issues related to rights that the board issues or grants, such as convertible debt instruments, options and warrants;

7) A report of the board meetings and the names of members who attended during the past financial year;

8) An account of any waivers to any rights of the board of directors. senior executives or shareholders of the listed company to dividends or compensation;

9) The annual audit results of the value of the corporation's internal control measures.

The CRSD and the CMA Board have judged many cases related to disclosure and transparency, mostly the non-application of these requirements by listed companies. Almost all such cases are subject to Article 9 of the CGR and Articles 43, 44 and 45 of the LR. ${ }^{56}$ The CRSD and the CMA Board enforced these resolutions. These match Article 59-B of the CML:

The Capital Market Authority Board may request the Committee for the Resolution of Securities Disputes to impose a fine upon the persons responsible for an intentional violation of the provisions of the Capital Market Law, the Implementing Regulations, and the rules of the exchange. As an alternative

\footnotetext{
${ }^{49}$ Hill (n 6) 54.

${ }^{50}$ Abdul Latif Bashik, 'A List of Corporate Governance and the Relationship with the Quality of Accounting Information and the Saudi Stock Market' in Corporate Governance Conference (Arabic edn, King Khalid University 2009) 5.

${ }^{51}$ Saad Al Mosa and Mohammad Al Abbas, 'Audit Delay: Evidence from Listed Joint Stock Companies in Saudi Arabia' (2005) KKUJ 7.

${ }^{52}$ Khalid Al Shaeed, 'The Association between Firm-Specific Characteristics and Disclosure: The Case of Saudi Arabia' (2006) 21(5) MAJ 491.

${ }^{53}$ Richard Morris, 'Signalling, Agency Theory and Accounting Policy Choice' (1987) 18(69) ABR 54.

54 The UK Corporate Governance Code (Financial Reporting Council, September 2014) 27.

${ }_{55}$ LR (n 388) Articles 43, 44 and 45; CGR (n 7) Article 9. Also, the CMA Board issued Resolution No 1-36-2008, dated 10 November 2008, making Article 9 of the CGR compulsory for all listed companies.

${ }^{56}$ Sanctions and penalties are studied first by the General Department of Corporate Governance. The author visited this Department and saw its work plan for the process for the CMA Board to consider punishment of violations by listed companies. The department examines the listed companies' article of associations, website announcements and board annual reports. Before determining violations of CGR and relevant articles of Implementation of Regulations, particularly the LR, the Department refers the decision to the CMA Board, along with proposals, recommendations for each fine and an explanation of its decisions.
} 
to the foregoing, the Capital Market Authority Board may impose a fine upon any person responsible for the violation of the Capital Market Law, the Implementing Regulations, and the rules of the exchange. The fine that the Committee for the Resolution of Securities Disputes or the Capital Market Authority Board can impose shall not be less than $\$ 2,666$ and shall not exceed $\$ 26,666$ for each violation committed by the defendant. ${ }^{57}$

Companies which did not comply with the corporate governance principles failed to include in their board annual reports the necessary information related to the practice of disclosure and transparency mandated by the CGR and LR. However, the failure of some listed companies to adhere to disclosure and transparency requirements is not uncommon. Theoretically, the rules and principles of disclosure and transparency are clear but, in practice, the application of such rules is generally weak, possibly attributable to soft follow-up by the CMA Board with fines and punishments not severe enough to be a deterrent. A better mechanism is needed to compel listed companies to fulfil the requirements of disclosure and transparency. For instance, instead of the CMA Board, the CRSD could mediate cases dealing with any violation of the rules by listed companies in order to make them pay attention to the requirements when preparing their board annual reports.

The Saudi disclosure and transparency requirements, if applied by enough companies to avoid violating the rules and suffering the consequent penalties, can enhance corporate governance in the Saudi capital market. Corporation board members and top executives must develop and apply such rules and principles. Listed companies have violated the following principles of disclosure and transparency.

1) The principle in Article 9-F of the CGR:

Any punishment or penalty or preventive restriction imposed on the company by the Capital Market Authority Board or any other supervisory or regulatory or judicial body (to be mentioned in the board annual report). ${ }^{58}$

This principle was violated by some companies, including the Saudi International Petrochemical Company. A case was brought against it when the company's 2009 annual financial report failed to mention that the CMA Board sentenced it at the beginning of that year. Consequently, it was fined by the CMA Board. ${ }^{59}$ In another example of a violation, the Al Ahsa Development Company did not include required information in its 2010 annual financial report and was fined $\$ 26,666$ by the CMA Board. ${ }^{60}$ These fines were imposed lawfully under Article 9-F of the CGR. The CMA Board makes an effort to ensure that listed companies abide by the CGR by following up on the application of disclosure and transparency and imposing penalties and other punishments. Thus, any sentence should be mentioned in the company's annual report. Failure to do so is considered a violation of the rules and regulations set by the CMA, CRSD and other Saudi judicial organisations. ${ }^{61}$

2) The principle in Article 9-B of the CGR:

Names of any joint stock company in which the company board of directors' member acts as a member of its board of directors (to be mentioned in the board annual report). ${ }^{62}$

An example of the violation of this principle comes from the Al Baha Investment and Development Company. Its 2010 board annual financial report did not mention the names of those serving as board members in more than one company. The CMA fined this company $\$ 13,333$. This is a typical punishment for a violation of the above principle. ${ }^{63}$ In such cases, it is suggested that the CMA Board should warn or fine persons who are members of more for not displaying this information appropriately. This will help in dealing with conflicts of interest. $^{64}$

3) The principle in Article 44-C of the LR:

\footnotetext{
${ }^{57}$ CML (n 5) Article 59(B).

${ }^{58}$ CGR (n 8) Article 9(F).

${ }^{59}$ Issued Decision, dated 15 August 2010 by the CMA Board.

${ }^{60}$ Issued Decision, dated 24 October 2010 by the CMA Board.

${ }^{61}$ Al-Riyadh Newspaper (25 October 2010) Issue 15463.

${ }^{62}$ CGR (n 8) Article 9(B).

${ }^{63}$ Issued Decision, No. 5-32-2011, dated 23 October 2011 by the CMA Board.

${ }^{64}$ Al-Riyadh Newspaper (24 October 2011) Issue 15827.
} 
The company shall announce, through the electronic applications, its interim and annual accounts immediately upon approval by the board and such statements must not be published to the shareholders prior to their announcement in the stock exchange. ${ }^{65}$

Regarding violations of this Article, the Southern Province Cement Company was fined $\$ 13,333$ by the CMA. In 2008, the company published its profits by posting the chairman of the board's speech online, which is not considered an official declaration, before informing the CMA and the Stock Exchange of its profits. ${ }^{66}$ This decision was issued in accordance with Article 9-J of the CGR, which states that 'the stock exchange shall be immediately informed of the results of the corporation general meeting. ${ }^{67}$

The fine imposed on this company is quite fair. It is in accordance with the regulations and rules set by the CMA and the SSE as they are the authorised and responsible bodies concerned with stating the behaviour of the listed corporations. Corporations must inform these official bodies of the board's annual financial report and any other important information, and not publish information before the stated time in order to ensure the fairness of the market. Conduct to the contrary constitutes legal grounds for punishment. ${ }^{68}$

4) The principle in Article 45-9 of the LR:

A description of the listed company dividends policy (to be included in the board annual financial report). ${ }^{69}$

An example of a violation of this principle is the case involving Alahli Takaful Company. The company's 2009 annual financial report did not explain its dividend rule. The CMA Board fined it $\$ 13,333$ in accordance with this Article. ${ }^{70}$ The annual financial report must detail the distribution of dividends to all shareholders to ensure equitable treatment.

Legally, this case follows the CMA rules regarding the corporations that breach this principle. However, it is suggested that the imposed fines be increased to prevent such violations and emphasise the significance of disclosing the distribution mechanism for dividends in order to protect shareholders' rights. The means of distributing dividends is required to be stated only in the company's articles of association and ordinary general meeting and is not stipulated by the CGR or LR. Therefore, it is recommended that the CGR mandate disclosure of the dividends distribution policy. ${ }^{71}$

5) The principle in Article 45-21 of the LR:

A statement of the amount of any outstanding statutory payment on account of any zakat, taxes, fees or other charges with a brief description and the reasons therefore (to be included in the board annual report). ${ }^{72}$

Saudi Fishers Company violated this principle with its 2009 annual report as it did not include the zakat and income tax it had paid. The CMA Board imposed a fine of $\$ 13,333$ on the company according to the above principle. ${ }^{73}$ Zakat is a certain amount of money deducted from the rich to be given to the poor and is one of the pillars of Islam. Paying zakat demonstrates that the company is fulfilling its duty towards society. Doubling this fine is suggested to act as a deterrent.

6) The principle in Article 45-11 of the LR:

A description of any interest, options and subscription rights of the company directors, senior executives and their spouses and minor children in the shares or debt instruments of the company or any of its subsidiaries, together with any change to such interest and rights during the last financial year (to be mentioned in the board annual report). ${ }^{74}$

\footnotetext{
${ }^{65}$ LR (n 388) Article 44(C).

${ }^{66}$ Issued Decision, dated 1 December 2010 by the CMA Board.

${ }^{67}$ CGR (n 8) Article 9(J).

${ }^{68}$ Argaam <www.argaam.com/article/articledetail/87076> accessed 1 November 2012.

${ }^{69}$ LR (n 388) Article 45(9).

${ }^{70}$ Issued Decision, dated 16 August 2010 by the CMA Board.

${ }^{71}$ Said Yahya, The Summary of the Saudi Arabian Commercial System (Arabic edn, The Bureau of Modern Arab 2004) 255.

${ }^{72}$ LR (n 388) Article 45(21).

${ }^{73}$ Issued Decision, dated 23 August 2010 by the CMA Board.

${ }^{74}$ LR (n 388) Article 45(11).
} 
In its 2009 annual financial report, STC did not mention the interests, preferences and donation rights of its board members and top executives. As a result, it was fined by the CMA Board. ${ }^{75}$ Since this case involved a major company, the CMA could suggest that it be arbitrated by the CRSD. STC's behaviour could be attributed to a conflict of interest among its board of directors, so the CMA might not be capable of handling it well. In such a case, it could have been presented to the CRSD. ${ }^{76}$

7) The principle in Article 45-3 of the LR:

A summary, in the form of a table or a chart, of the assets and liabilities of the company and of the company's business results for the last five financial years or from incorporation, whichever is shorter (to be included in the board annual report). ${ }^{77}$

Arabia Co-Operative Insurance Company provides an example of a violation of this principle. Its 2010 board annual financial report did not include accurate figures for company assets and liabilities nor did it mention any business results for the past five financial years. In this case, the CMA imposed a fine imposed in accordance with Article 45-3 of the $\mathrm{LR}^{78}$ which requires accurate figures describing the company's performance in the most recent five years to be provided in the annual report. The company deserved such punishment in order to encourage the application of disclosure and transparency, and to provide investors with useful information about the company's productivity and an analysis of business results in recent years. ${ }^{79}$

8) The principle in Article 43-A of the LR:

A corporation must notify the Capital Market Authority and the public without delay of any major developments in its sphere of activity which are not public knowledge and which may have an effect on the corporation's assets and liabilities or financial position or on the general course of its business. ${ }^{80}$

In addition, Article 43-B-7 of the LR stipulates that 'the increase or decrease in the net assets of the company equal to or greater than $10 \%$... be included in the board annual report ${ }^{81}$ Al Masafi Saudi Arabian Company violated the above-mentioned principle by failing to notify the CMA and SSE about its board recommendations to increase its capital by the deadline of July 2008. For this violation, the CMA Board fined the company $\$ 26,666 .^{82}$ A company that intends to increase its capital should notify the CMA and SSE; otherwise, it will be liable to a penalty as occurred in this example. ${ }^{83}$

9) The principle in Article 43-B-2 of the LR:

Any debt outside the company's ordinary course of business, in an amount equal to or greater than $10 \%$ of the book value of the company's net assets (to be included in the board annual report). ${ }^{84}$

In a 2011 board annual financial report, the Saudi Cement Company did not mention its debt to the Samba Financial Group. Under the above principle, the CMA punished this company with a fine ${ }^{85}$ Violations of this principle hide important company information and concerns from the CMA and investors. This weakens the application of disclosure and transparency. The penalty for such violations and the application of these rules should be strengthened, such as by postponing trade in shares of the violating company and informing investors about such behaviour. ${ }^{86}$

\section{Problems in Cases of Inadequate Disclosure}

If disclosure is insufficient, problems arise, such as a lack of transparency due to weak rules or application. Abuse will prevail in the market and securities, and investors will lose confidence in the market activities.

To meet these challenges, the CML contains provisions to enhance transparency. This law requires the

\footnotetext{
${ }^{75}$ Issued Decision, dated 27 June 2010 by the CMA Board.

${ }^{76}$ For more information see <www.argaam.com/article/articledetail/165829/> accessed 1 November 2012.

${ }^{77}$ LR (n 388) Article 45(3).

${ }^{78}$ Issued Decision, No. 6-28-2011, dated 18 September 2011 by the CMA Board.

${ }^{79}$ For more information see <http://www.argaam.com/article/articledetail/229910/> accessed 1 November 2012.

${ }^{80}$ LR (n 388) Article 43(A).

${ }^{81}$ ibid Article 43(B-7).

${ }^{82}$ Issued Decision, dated 1 December 2008 by the CMA Board.

${ }^{83}$ Aleqt (1 December 2008) Issue 55350.

${ }^{84}$ LR (n 388) Articles 43(B-2).

${ }^{85}$ Issued Decision, No 4-23-2011, dated 3 July 2008 by the CMA Board.

${ }^{86}$ For more information see $<$ http://www.argaam.com/article/articledetail/219441/> accessed 1 November 2012.
} 
publication of a prospectus for the firm to be listed. The required information in the prospectus includes the issuers of the securities, their business activities, the individuals in charge of management, the principal shareholders and any information material to assessing the risks of investing in the stock.

The prospectus is more than a mere brochure because it commits the firm to the truthfulness of all information in it. An investor who buys primary shares on the basis of the information in the prospectus may file for damages against the firm if any inaccurate material information was presented in or intentionally omitted from the prospectus. ${ }^{87}$ In a few instances, the prospectus is not required but these are few and act more as exemptions, with the general rule favouring full disclosure in the prospectus.

A number of additional obligations are imposed on certain sectors, such as insurance and mining, as they are associated with greater public risks. However, a gap in the rules governing disclosure favours listed companies. Article 26 allows for the waiver of disclosure requirements when, in the opinion of the issuer, the disclosure would be detrimental to the issuer, and the omission is not likely to mislead investors' assessment of the securities. ${ }^{88}$ Application for the waiver, of course, must be made to authorities, and in the course of the application the nature of the waived information should be made evident.

This measure might be necessary, especially in highly competitive firms that maintain industrial secrets. However, the provision is also open to abuse and possible connivance between authorities and the issuer to allow more than necessary leniency for the non-disclosure of matters vital to the investor but unfavourable to the image of the issuer. This defect in the provision is highlighted by its failure to qualify in what manner the undisclosed information would be 'unduly detrimental' to the issuer. Admittedly, this description could cover a broad range of situations and even be used to exempt the disclosure of information which impinges significantly on public interest. $^{89}$

\section{Regulations Addressing Market Abuse}

Lapses in compliance with disclosure and transparency standards are hugely detrimental to the effective functioning of the financial markets and slow down economic development. A lack of transparency can result in insider dealing, conflicts of interest and price manipulation in the stock exchange, among other adverse repercussions. Stock market regulators are aware of the possible loopholes in market regulation and have intensified efforts to eliminate irregular trading and poor disclosure in order to encourage more participants to invest in the equities market. In the SSE, most trading is conducted by retail investors who are the most vulnerable parties because of the danger of losing their life savings to unscrupulous market players. ${ }^{90}$

\subsection{Market Manipulation}

It has been observed that market manipulation takes place in all stock markets, even developed ones although arguably to a much lower degree. An aim of the SSE is to reduce the frequency and severity of market manipulation. Jarrow argues that only major investors can change prices to manipulate the market for their own interest. ${ }^{91}$ He differentiates between the manipulator and the major trader and views market manipulation trading positively as it accumulates wealth without risk. Jarrow thinks that although other people believe the major trader has sensitive information and behaves accordingly, the major trader actually controls prices through the large size of his trade..$^{2}$

However, Gale and Allen identify intentional stock price manipulation as a major issue throughout history. Market manipulation generally has been viewed as immoral behaviour since the founding of the first stock exchanges. Early brokers manipulated stock prices by quickly selling certain securities. Prices fell when fearful investors also sold them, and then brokers bought the shares back at a lower price. Early brokers also made profits by spreading false rumours about company's prospectuses. ${ }^{93}$

Article 49 of the CML defines market manipulation as any act which creates a false or misleading impression of the market or the prices or the value of securities. Market manipulation also includes inducing third parties to buy, sell or subscribe to securities or to refrain from doing so or to permit or prevent them from exercising the

\footnotetext{
${ }^{87}$ Baamir (n 382) 72.

${ }^{88}$ LR (n 388) Article 26.

${ }^{89}$ ibid Article 26; Baamir (n 382) 70.

90 Dominic Dudley, 'Riyadh Tightens Market Regulation' (May 2013) 57(27) MEED 18.

${ }^{91}$ Robert A Jarrow, 'Market Manipulation, Bubbles, Corners and Short Squeezes' (1992) 27(3) JFQA 311.

92 ibid.

${ }^{93}$ Franklin Allen \& Douglas Gale, 'Financial contagion' (2000) 108(1) JPE 1.
} 
rights associated with such securities. Other methods of manipulation of securities prices include conducting false sale activities without real transfer of ownership. ${ }^{94}$ Such behaviours prevail in Saudi Arabia due to the weak actions of the CMA and the structure of ownership. ${ }^{95}$

In deceptive transactions, an investor sells securities from one fund and buys the same amount from another fund which he manages. This practice creates the impression that trading in this share is active which increases in its price. Such practices are enabled by a lack of market education among investors and a scarcity of expert market makers. Tracing such practices in the Saudi market, Taher noticed that the share prices of 70 out of 81 companies traded in the market were overvalued as a result of mass speculation. Within a month, the price of the securities of some firms rose $200 \%$ despite losses, leading to a sharp price correction. ${ }^{96}$

Among the harmful effects of such practices are that investors who suffered losses might not be able to raise local funds later or subscribe widely to future IPOs. These practices have created social crises that have negative consequences for many people..$^{97}$

The FSA classifies market manipulation as three offences: firstly, encouraging transactions in an investment by giving a misleading impression of the supply, demand or price to keep the price of that investment at an abnormal level; secondly, entering into transactions to trade that employ fictitious devices; and thirdly, spreading misleading information about a financial instrument.

In February 2006, a great crash in the Saudi market caused financial catastrophe, especially for small investors. Looking for the reasons behind the crash, specialists argued that market manipulation was among the main causes. Consumers started to spend less due to the financial crisis, and the CMA has fought against the negative consequences of the crash.

After a prosperous period, the SSE reached more than 20,000 points in February 2006 but then collapsed by 50\%. Despite a lack of proactive measures, the CMA responded by taking steps to protect investors. ${ }^{98}$ These measures lowered the daily fluctuation rate in the SSE from 5\% instead of 10\%. The CMA attempted to increase market liquidity and transparency in capital market activities and allowed foreign residents to trade directly with local exchanges. ${ }^{99}$ In addition, the CMA aimed to prevent market manipulation. It declared that, in early February 2006, three investors had violated CML Article 49 by creating a false impression of the prices of securities of the eight firms. As a punishment, the CMA levied a large fine against the investors and banned them from working in listed firms or trading in the market for three years. However, the CMA did not give any details about how the manipulation took place.

Dudley states that there 'is a widespread acknowledgement that market manipulation almost certainly happens in some corners of the Tadawul'. ${ }^{100}$ Regulations are in place but are not well enforced by the CMA, which often resorts to charging and collecting fines from those who violate regulations. The CMA has imposed $\$ 140,000$ fines on companies trading on the SSE, mostly from penalties for failing to disclose important information about companies. For instance, the Saudi Kayan Petrochemical Company was fined SR50,000 in April 2013 for failing to disclose the expected financial impact of stopping production at some units for maintenance. In May 2013, the United Cooperative Assurance Company was fined SR100,000 for not disclosing its financial results for the previous year. ${ }^{101}$

Despite these disciplinary actions, violations of the stock market regulations still occur. The fines are not high enough compared to companies' net profits to act as deterrents. The SR50,000 fine imposed on Rabigh Refining and Petrochemical for violating Clause (A) of Article (40) of the LR and Sub-clause (5) of Clause (A) of General Instructions was taken into account by companies in the announcement published by the SSE on 15 December

${ }^{94}$ CML (n 5) Article 49.c.1.a.

${ }_{95}$ Market abuse is not a criminal offence in Saudi Arabia, and the CML 2003 is the first regulatory step to tackle this issue.

96 Thehad A Clearer Path for Investors

$<$ http://www.thebanker.com/World/Middle-East/Saudi-Arabia/A-clearer-path-for-investors?ct=true $>$ accessed 26 July 2014.

${ }^{97}$ All the IPOs in the SSE have been massively oversubscribed.

98 The CMA did not intervene to eliminate market manipulation before the crash in February 2006.

99 IMF (2006).

${ }^{100}$ Dudley (n 471) 18-21.

${ }^{101}$ CMA, 'Announcement of the imposition of a penalty' (26 May 2013), 'The Capital Market Authority announces the issuance of a CMA Board resolution to impose a penalty of SR 100,000 (One Hundred Thousand Saudi Riyals) on United Cooperative Assurance Co. Due to its violation of clause (A) of Article (45) of the Capital Market Law and clause (E) of Article (42) of the Listing Rules. The company failed to inform CMA or announce to the shareholders its annual financial statements for the period closing on 31/12/2012 within a period not exceeding Forty days from the end of the financial period covered by those statements'. 
2013. It contained false information on reaching an agreement with shareholders to boost its financial performance. It claimed the agreement would have a financial impact of nearly SR1 billion of the company's revenues and SR1.3 billion in subsequent years. In future years, the financial effect will be only on the net profit.

\subsection{Irregular Trading}

Amidst inadequate disclosure, insider dealing flourishes. The practice is defined as using critical information about price in a firm before publishing it to gain financial benefits. Many countries have adopted legal measures to criminalise and prevent insider trading. According to Friedman, ${ }^{102}$ honest competition between the players in the capital market is necessary, and all players should have the same information in order to create a fair and competitive environment. No player should have access to insider information during the process of securities trading.

However, Manne ${ }^{103}$ argues that insider trading is fruitful because it creates company value, such as new investments. Similarly, Beny ${ }^{104}$ and Bhide ${ }^{105}$ contend that large shareholders' access to inside information enables them to obtain greater trading profits than other shareholders, which serves as compensation for monitoring the firm's performance and guiding it to avoid risks. Carleton and Fischel ${ }^{106}$ likewise assert that insider trading can be considered compensation for managers as they direct the company, and this motivates them to provide better management. Without the benefits of insider trading, the researchers argue, managers would less productive.

Other specialists take an opposing view of insider trading. Among them, Gilligan advocates preventing insider trading as it creates an imbalance of opportunities and perpetuates unfairness, abuse of position and confidential information, and loss of integrity and confidence. ${ }^{107} \mathrm{He}$ explains that insider dealing negatively affects liquidity and increases opportunities for serious abuse and crime. Rider and Ashe ${ }^{108}$ contend that insider dealing should be controlled because it harms confidence, allows the abuse of trust and supports unfairness.

Insider trading can be seen in abnormal, unusual fluctuations in the value of a company's stock. Meulbroek ${ }^{109}$ finds that illegal trading based on inside information caused stock price run-ups of target firms before takeover announcements.

Nevertheless, insider trading is not completely illegal, some aspects of it are legal. Some members of companies, such as managers and employees, may trade in stock in their own firms on the condition that they report their trades to the relevant bodies of the stock market. This practice is permitted even though insider trading often accompanies illegal trading of stock. In fact, illegal insider trading is considered that which occurs when buying or selling a security in violation of a regulatory rule or a relationship of trust and confidence at the time of possessing sensitive private information about the security. According to the SSE, the concept also includes misappropriation of such information. ${ }^{110}$

Article 35 of the LR prohibits trading by company insiders ten days before the end of a quarter or the publication date of the quarterly report, whichever is shorter, and 20 days before the end of a financial year or the publication of the interim account. The CMA used these regulations to fine more than forty insiders at thirty-five companies for insider trading during the prohibited periods. The CMA referred some insiders for investigation about the release of material information. ${ }^{111}$

The absence of transparency allows insider trading to flourish. In response, the CMA enacted stricter regulations, including judiciary measures seven years ago. Under these regulations, the CMA investigated hundreds of cases of the market, and referred approximately 30 to court. Some parties involved were fined and even imprisoned. ${ }^{12}$

\footnotetext{
${ }^{102}$ Benjamin M Friedman, 'The use and meaning of words in central banking' in Paul Mizen (ed), Central Banking, Monetary Theory and Practice (Edward Elgar 2002).

103 Manne H, Insider Trading and The Stock Market (The Free Press 1996).

${ }^{104}$ L Beny, 'The political economy of insider trading legislation and enforcement (Harvard Law School OLIN Working Paper, 2001)

105 A Bhide, 'The hidden costs of stock market liquidity' (1993) 34 JEF 31.

106 D Carleton and D Fischel, 'The regulation of insider trading' (1983) 35 Stanford Law Review 857.

107 George P Gilligan, Regulating the Financial Service Sector (Kluwer Law International 1999) 217.

108 BAK Ryder and Michael Ashe, Financial Services Law (Butterworths 1999).

${ }^{109}$ L Meulbroek, ‘An Empirical Analysis of Illegal Insider Trading' (1992 47 JF 1661.

${ }_{110}$ Baamir (n 382) 74.

111 ibid 75

112 Tadawu, 'The Saudi Stock Market: Structural Issues, Recent Performance and Outlook' (Samba, 13 December 2009) $<w w w . s a m b a . c o m / G b l D o c s / S a u d i \_S t o c k \_$Market_Eng.pdf> accessed 26 June 2013.
} 
In April 2013, the CMA issued a statement that it had detected 'irregular trading activity' in the stock trading of three listed companies suspected of violating the agency's rules and regulations. The named firms were Tihama Advertising and Public Relations Company, Tourism Enterprise Company and Saudi Indian Company for Cooperative Insurance. In its statement, the CMA pledged to investigate these companies but as of July none had been held accountable. ${ }^{113}$

The strong financial position and continuous progress of a company's operations encourage investment. Based on misleading information, these companies' securities increased, and the major shareholder sold his shares a few days later without notifying the CMA Applying Article 50(a) of the CML and Article 30 of the LR, the authority suspended all trading in the market until further notice and started investigating the case. ${ }^{114}$ The CMA press release did not mention the names of the insiders or the amount of loss caused to other investors.

In addition to companies, the CMA punishes individuals. In at least nine cases in 2013, the CMA fined individuals a total of SR950,000 for dealing in securities without securing the proper authorisation. The fines ranged from SR50,000 to SR200,000. Many such enforcement actions are hidden from the public, conducted in private, negotiated settlements. ${ }^{15}$ These settlements let companies and individuals escape the notoriety of committing a dishonest act in the finance industry, which requires a reputation for honesty and integrity.

\section{3 'Name and Shame'}

In the financial industry, reputation is given much weight because of the fiduciary trust due to one's financial partners and collaborators. Consequently, a financial practitioner or institution suffers from being found guilty and fined for violating CMA regulations. Tim Please, a lawyer at the Saudi-based Clifford Chance International Law Firm, calls this the 'name and shame' penalty, explaining that 'some sanctions are never put to a name'. ${ }^{116}$ The practice is to publicly state that the offending company broke a different rule, such as accounting regulations or filing deadlines for financial statements, which does not appear as malicious as fraud charges.

In the Saudi stock market, $85 \%$ to $90 \%$ of the trades are done in the name of retail investors, or local individuals trading through brokers. Retail investors often lack information and professional advice and typically engage in trading driven by sentiments (i.e. fear and greed), not deep analysis. Markets dominated by these investors experience volatility and market swings which sometimes gives the impression of irregular or insider trading. Therefore, it is important that the SSE develop larger investor groups (such as mutual funds) or institutions to stabilise markets driven by professional analyses, not emotional trading. Opening up stock exchanges to international investors could have the same effect. The recent appointment of Mohammed al-Sheikh as chairman of the CMA's board of governors might also help reduce volatility. Al-Sheikh, a former lawyer in Washington, $\mathrm{DC}$ and executive director of the $\mathrm{WB}$, has expressed receptiveness to the idea of opening the market to foreign buyers. ${ }^{117}$

\section{Regulatory Response to the Market Crash of February 2006}

A major cause of the market collapse of February 2006 was rampant market manipulation. Major speculators used their large resources in a relatively thin market to take advantage of more inexperienced retail investors trading in speculative shares. The relative inexperience of market regulators also contributed to the crash as they failed to detect market manipulation practices early enough to prevent abusive market activity.

Since the crisis, confidence in the SSE has gradually recovered although the CMA warns that a largely retail market with irregular trading patterns is prone to high volatility (i.e. sudden swings in market prices). After the crisis, a new market structure was introduced with the purpose of increasing transparency in the Saudi market by opening it to deeper, broader participation by institutional and foreign investors. ${ }^{118}$

\section{Saudi Compliance with the OECD Principles of Corporate Governance}

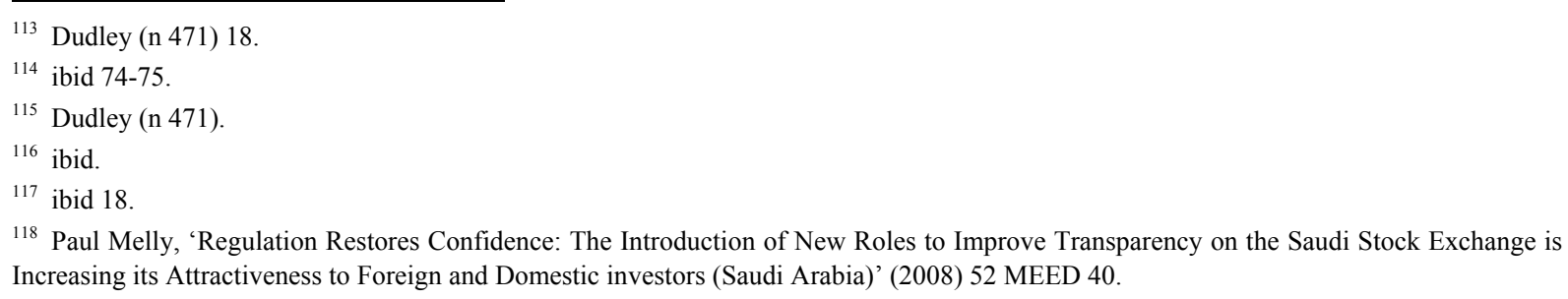


The previous section identified the three major legal issues concerning disclosure and transparency. This section examines the extent to which Saudi Arabia has complied with the OECD Principles of Corporate Governance. It evaluates specific areas that should be addressed by corporate governance principles.

\subsection{Investor Protection}

The Kingdom has complied with principles relating to basic shareholder rights. The Securities Depository Center has secured registration of shareholders ${ }^{119}$ and made company information easily accessible to all shareholders allowed to participate in GSMs in person or by proxy. These members can suggest inclusion of items in the GSM agenda, call for a GSM and nominate, vote for and remove board members. ${ }^{120}$

An extraordinary general assembly (EGM) is required to carry out activities, such as changing the company's articles of association, authorising large transactions and increasing authorised capital. When new shares are issued, shareholders have pre-emptive rights. Special attention is paid to the disclosure of related party transactions when the LR dictate prompt disclosure to the CMA in case any transaction is carried out between the company and a connected person. ${ }^{121}$ Any contract between the company and a director, CEO or chief financial officer should be reported to the board. Good corporate governance ensures that companies use their resources more efficiently in a way that protects minority shareholders, leads to better decision making and improves relations with workers, creditors and other stakeholders. It is an important condition for attracting the patient capital needed for sustained, long-term economic growth. ${ }^{122}$

Saudi Arabia's CGR does not reference related party transactions. This absence has raised concerns among many investors and brokers that industry insiders might abuse their positions and carry out improper activities, such as market manipulation, trading insider information and improperly trading with shares in investor accounts. ${ }^{123}$ In response to these concerns, the CMA issued a Market Conduct Regulation provision in the CML to ensure that 'insider trading' was well defined and prohibited in order to avoid market manipulation. ${ }^{124}$

Other liability provisions protect investors, although the general rule is that directors are not liable for the actions of the company, which is considered a separate legal person. This protection of directors, called the corporate veil, has exceptions under civil law. Directors are trusted by the owners of a company (the shareholders) to make decisions in their interest. These include investment decisions that should increase shareholders' wealth. ${ }^{125}$ For example, if a director pursues a business venture without consultation or researching it and the venture fails, he is personally liable for the loss. Directors who breach their duties can be held liable if the company incurs losses. Therefore, directors need to always carefully consider their actions to ensure that they are in the best interests of the company. They must discharge their duties honestly, in good faith and in the best interests of shareholders.

The recent growth in equity markets has spurred the emergence of a new class of financial intermediaries in the Kingdom, including research analysts, fund managers and investment managers. Their regulation falls under the mandate of the Authorised Persons Regulation to fulfil the major principles of the IOSCO 'Statement of Principles for Addressing Sell-side Securities Analyst Conflicts of Interest, 2003'. ${ }^{26}$ The CGR motivates finance managers to disclose their voting direction or policy in the GSMs of the companies in which they invest. This disclosure helps build a good business image of corporate governance. ${ }^{127}$

Such an image brings benefits to the market, including increasing funds and representation of foreign investors in the boards of the firms listed in Saudi Arabia. Representation of foreign investors in the boards can transfer ideas about global corporate management to Saudi firms. ${ }^{128}$ However, the SSE is weak and not in line with the indicators of even emerging markets; for example, Morgan Stanley assessed the SSE as having little foreign

\footnotetext{
${ }^{119}$ G Vinten, 'Corporate Governance: The Need to Know' (2000) 32(5) ICT 173.

${ }^{120}$ Al-Amari (n 152) 71.

121 ibid.

${ }^{122}$ WB (85) 3. See also Nasdaq Educational Foundation, 'Market Mechanics: A Guide to US Stock Markets Release 12' (2012)

$<$ http://www.nasdaq.com/about/market_mechanics.pdf $>$ accessed 9 May 2012.

123 ibid 3.

${ }^{124}$ CML (n 5) Articles 2, 3 and 4. See also WB (n 85) 3.

125 Saidi (n 327) 10.

126 OECD (n 42) 57.

127 ibid 3.

${ }^{128}$ T Fadak and H Aloiei, 'Stressing that Joining the Index Attracted Global Investors, Large Fund and Portfolios' (Aljajarh Newspaper, 17 June 2013) Issue 14872.
} 
ownership of companies, lacking certain tools and procedures and not applying best practices. ${ }^{129}$

CMA regulations govern takeovers. A shareholder who obtains more than $50 \%$ of company shares might be required by the CMA to make a tender offer for all outstanding shares. This measure serves as a protection mechanism, especially for minority shareholders. ${ }^{130}$

\subsection{Disclosure}

Companies in Saudi Arabia are expected to produce quarterly and semi-annual financial statements, which include balance sheets, profit and loss accounts, notes, audited annual reports and cash flow statements. ${ }^{131}$ Annual reports should describe the issuer, its business, board information, officers and issuer's staff. In addition, annual reports should include a management statement that highlights the present and future developments that are expected to have significant impacts on the firm's financial position. ${ }^{132}$ Various Saudi companies provide this and other information on their websites. ${ }^{133}$

It is important to note that compliance with non-financial disclosure requirements has been described as weak. Despite the low level of compliance, the LR appears fairly complete and requires significant disclosure. Although companies are expected to disclose some important information, such as corporate objectives, dividend principles and board composition, it is clear that disclosure remains haphazard, especially in areas dealing with nomination procedures, board member qualifications and ownership benefits. ${ }^{134}$

The corporate governance framework calls for the disclosure of the beneficiaries but only to the CMA, not the public. A shareholder who exceeds the 5\% threshold must inform the company and CMA, which may decide whether to make that information public. An online initiative called Tadawal publishes ownership information of shareholders with both more or less than $5 \%$. Although annual reports are expected to give information about significant shareholders, public disclosure of beneficial ownership has remained a major concern, making Tadawal a noteworthy initiative. ${ }^{135}$

Financial statements should be prepared in accordance with local accounting standards and the financial reporting requirement. The Ministry of Commerce and Industry requires that all companies keep Arabic language accounting books and records within the Kingdom. These documents include the general ledger, daily journal and inventory book. ${ }^{136}$ The inventory book includes a detailed trial balance of all the assets, liabilities and performance for the financial year. It should be comparable with a detailed income statement and balance sheet.

Companies operating and registered in Saudi Arabia must comply with SCOPA accounting standards. International Financial Reporting Standards can be used as a guide in cases where the SOCPA principles do not apply. However, most companies are encouraged to apply the international standards as more than a guide in order to attract investors. During a lecture entitled 'Presentation and Disclosure in the Financial Statements of Companies' given in Mecca at an Industry and the Chamber of Commerce event, the engineer Adel emphasised the importance of applying international standards. Doing so enables investors to invest in countries other than their own. The difficulties of applying and implementing different accounting standards can prevent investors from entering into a market in other countries. ${ }^{137}$

The following are the main accounting and auditing regulations: International Financial Reporting Standards; SOCPA standards; company regulations; income tax regulations; and additional accounting standards issued by the SAMA for financial institutions.

These statements are then audited according to the National Standards of Auditing. The SOCPA standards do not in any way converge with the International Financial Reporting Standards. ${ }^{138}$ Although compliance with national standards has been found to be quite high, there is a strong push to converge the two standards in order

\footnotetext{
129 ibid.

${ }^{130} \mathrm{WB}(\mathrm{n} 85) 3$.

131 CML (n 5) Article 45.

${ }^{132}$ WB (n 85) 4. See also LR (n 388) Articles 43, 44 and 45. See also CGR (n 8) Article 9. Also, the CMA Board issued Resolution, No 1-36-2008, dated 10 November 2008 making Article 9 of the CGR compulsory on all listed companies.

${ }^{133}$ Al-Nodel and Hussainey (n 84) 13.

${ }^{134}$ WB (n 85) 4.

135 ibid.

${ }^{136}$ Latham \& Watkins (n 94) 20.

${ }^{137}$ E Hjebaljmah, Presentation and Disclosure in Financial Statements (2012) Issue 16041.

138 AAM Al-Twaijry, JA Brierley and DR Gwilliam, 'An Examination of the Role of Audit Committees in the Saudi Arabian Corporate Sector' (2003) 10(4) Corporate Governance: An International Review 288.
} 
to improve financial reporting and assure investors. ${ }^{139}$ The legal basis for implementing accounting and auditing standards are quite explicit, and SOCPA's authority is generally respected. However, the quarterly reviews of the audits are considered ineffective. ${ }^{140}$ Some have called for real-time disclosures in both Arabic and English in order to resolve 'the irregularities and abuses among traders in a fair and firm way in front of everyone'. ${ }^{141}$

\subsection{Enforcement}

The CMA has the mandate to examine and take enforcement action. For example, in 2006, 83 cases were forwarded to the CMA, some through shareholder's referral reports. ${ }^{142}$ A good number of these cases involved market manipulation and disclosure delays. The administrative remedies and penalties at the CMA's disposal are daily suspension of trading activities, warnings, penalties and cease and detest orders. ${ }^{143}$ The CMA must present cases warranting heavy fines or imprisonment to another body.

The CMA understands the need for better corporate governance and has adopted a three-phase approach to improve the implementation of corporate governance. In the first phase, the CMA published the CGR ${ }^{144}$ and in the second, it educated market participants about how to apply regulations. In the third phase, the CGR will be revised, and all sections of regulation made mandatory. Corporate governance in Saudi Arabia is still a promising aspect because the CMA is working to educate market players on the importance of implementing and applying corporate governance. ${ }^{145}$

\section{Development of Saudi Regulations}

Saudi laws, especially those related to the concepts of disclosure, transparency and listing rules, need reforms. Ways to increase the application of these concepts need to be found. The CML and LR regulations dealing with disclosure seem identical to the recommendations of IOSCO and the Basel Committee and the standards of developed countries' markets, particularly the LSE and NYSE. Jurisdictions vary between countries.

Any reforms of disclosure rules and provisions of disclosure require a good understanding of the market structure and investors' thinking. In 2004, the SSE was extremely attractive. ${ }^{146}$ Although owners directly managed most funds in the market, most investors did not have enough experience to manage their investments. This environment encouraged major speculators to manipulate the market, spreading rumours and making false transactions. One suggestion to prevent such misbehaviour and strengthen transparency is to encourage investment institutions to participate in the market in order to support fair competition based on transparency and increased, sufficient publicly available information.

Usually, the available information about the SSE is thought to be true. In an attempt to strengthen transparency and disclosure in the capital market, the CMA takes disciplinary actions to punish firms that do not publish interim accounts on time or comply with the necessary standards. ${ }^{147}$

Investors and interested parties can look for information about the market, securities and related issues on the websites of companies, newspapers, the CMA and Ministry of Commerce. Specialised institutions authorised by the CMA evaluate new corporations to gain objective, trustworthy information and make it available to investors.

\footnotetext{
139 Tsamenyi \& Uddin (n 373) 1.

${ }^{140}$ Vinten (n 500) 173.

${ }^{141}$ M Omran, 'Stressing that Joining the Index Attracted Global Investors, Large Fund and Portfolios' (Aljajarh Newspaper, 17 June 2013 ) Issue 14872.

${ }^{142}$ WB (n 85) 6.

143 ibid 6 .

144 ibid 6.

${ }^{145}$ WB (n 85) 6.

${ }^{146}$ A Al-Ghadeer, 'Saudi banks have conflicts of funds in the shares of loss-making companies' (2006) Issue 13994.

${ }^{147}$ Establishment of the first stock company in the Kingdom goes back to the third decade of the $20^{\text {th }}$ century, but stock trading found its way in the Kingdom by the end of the nineties, which witnessed substantial increase in the number of stock companies. In 1984, a Royal decree was promulgated for regulating stock trading through local banks, and forging of ministerial panel for supervision of the market, which has among its members the Minister of Finance, the Minister of Commerce and the governor of Saudi Monetary Agency. The Saudi Monetary Agency was entrusted with day-to-day control and supervision of the market activities, effective as from the first half of 1986. In 1990, the first electronic integrated system, known by the name of ESIS, was introduced for settlements and clearing, and the launching of the TADAWUL system in October 2001 with its cutting-edge technology added new dimensions to trading system. As a part of the extensive regulatory developments which are mainly designed for keeping pace with the world developments, and for enhancing of the investment environment, the Kingdom has reviewed and upgraded many of the already existing regulations and systems, and new regulations, that cope with the development and modernization process, were issued. At the top of these regulations is the enactment of the Capital Market Law, which is mainly designed for restructuring the capital market in the Kingdom, benefiting from the most up to date international applicable standards (SSE).
} 
However, insufficient company disclosure was not the main reason for price manipulation in the SSE. Among the others, the most important is small investors' lack of experience. They do not know how to manage their funds or to get and use information, and need to be educated about the conditions of the financial market and how to achieve their goals. In order to educate this type of investor, the CMA has begun running specialised programmes and bulletins on television and in newspapers to warn small investors about the dangers of rumours in securities trading. The agency also tries to explain the correct way to get credible information and encourages using investment funds. Another method of education could be to offer courses through licensed institutions to enable small investors to manage their investments and do so under market mechanisms. ${ }^{148}$

Another cause of price manipulation was a gap in rules disclosure regarding notification about any person who owns $5 \%$ or more of any class of voting shares or convertible debt instrument and about any increase or decrease by $1 \%$ or more in an issuer's ownership. ${ }^{149}$ Such notification must be given by the end of the trading day. This raises the question: What if a speculator buys and sells shares within one trading day? To address this gap, the CMA needs to control and monitor the market more strongly. It has taken some steps to do so, including establishing the Securities Depository Center. This centre controls the most important activities, namely executing transactions, transferring, settling, clearing, and registering ownership of securities traded on the SSE. Through this centre, the CMA can track all transactions, ownership transfers, security trading details and other market activities and investigate whether they are legal. The CMA thus exercises its power to prevent the illegal dealings in the market. ${ }^{150}$

Suspicious deals and price manipulation can be detected by comparing the amount of securities traded on the individual level by investors. Some stock exchanges use technology to issue notifications and warnings about suspected trading deals and price movements in the market. Specialist staff examine these notifications when needed. ${ }^{151}$ In addition, false transfer of ownership — when an investor sells and buys in different funds he owns and changes prices without an actual transfer of ownership — can be detected.

It has become clear that the SSE suffers from price instability and desperately needs a solution to control the risk of price manipulation. To that end, it is proposed that the percentage of shares which must be reported to the SSE as securities when the price fluctuates during trading is less than $5 \%$ of a total class of a firm's shares. To develop possible solutions to market manipulation, the CMA has made use of the experience of developed markets, especially the UK. Despite great efforts to control mass speculation, the CMA lacks experience of doing so, and relying on other countries' experiences saves time. Price manipulation could also be stopped through jurisdiction punishments against offenders with the aim of deterrence.

To some extent, the CMA regulations are too loose and not strong and strict enough, and allow industry insiders and market manipulators some protection to achieve their goals. Fines levied by the CMA go to the agency itself $^{152}$ even though it does not suffer any damage from violations. Logically, the harmed investors should receive these fines as compensation for their losses and appropriate punishment of manipulators. Islam considers abusive behaviour in the market to be prejudicial and prohibits insider dealing as cheating and a criminal offence. $^{153}$

Under the CML, major shareholders and insiders should notify the CMA about their investments, including its term, purposes of ownership, the financial source of the transaction and any changes in purpose. The law forbids insiders and major shareholders from disposing of their shares within ten days of the date of notification. As a proposal to increase the safety of safe market transactions, this period should be lengthened and these shareholders should be required to gain approval to dispose of their shares. ${ }^{154}$

Islamic law is flexible and can suit any place at any time. It addresses personal, social and economic issues. Almost all laws and regulations in Saudi Arabia are derived from its general guidelines and principles. The CML

\footnotetext{
${ }^{148}$ Saudi Stock Market Objectives: (1) Operate the market effectively and efficiently; (2) Ensure market integrity, quality, and fairness; (3) Support investor education and awareness efforts; (4) Develop service excellence for customers (brokers, issuers, investors, vendors, etc) and; (5) Develop the exchange's capabilities and competencies. $<$ http://www.tadawul.com.sa $>$ accessed 2 September 2014.

149 LR (n 338) Article 45.

${ }^{150}$ CML (n 5) Article 49.

${ }^{151}$ Securities and Exchange Board of India <http://www.sebi.gov.in/commreport/marketintegrity.html> accessed 15 September 2013. Market Integrity Disclosure, Homage of Securities Exchange Board of India.

${ }^{152}$ CML (n 5) Article 13(a).

${ }^{153}$ Islamic law does not stipulate any punishment for some prohibitions, either because discretion is permitted or they do not satisfy the conditions of a clear offence; among these is price manipulation.

154 The fashion of listing family companies in Saudi Arabia raises questions regarding their real value, profits and continuity.
} 
adopted the Islamic view of market transactions, prohibiting abuse as it harms other dealers in the market. However, the relevant bodies must revise the existing rules and laws to cope with new developments in the fields of finance and trade.

\section{Other Issues in Saudi Arabia's Business and Legal System}

\subsection{Duplication in the Company Law and the Corporate Governance Regulations}

While the CL and CGR are crucial measures in the governance framework, they overlap in certain areas, thus creating a certain amount of ambiguity in the interpretation of corporate requirements and standards. The CL is implemented by the Ministry of Commerce and Industry, and the CGR by the CMA. The CL oversees the establishment and regulation of all forms of companies allowed by law, including joint liability, limited partnerships, limited liability, professional and JSCs. ${ }^{155}$ The CGR is enforceable against Saudi listed companies that are traded on the SSE. The overlap occurs among listed companies regulated by both the CMA and the Commerce Ministry, creating a dual system of corporate governance for both the listed companies and the SSE. Compounding the dilemma is that the corporate governance provisions in the CL are not integrated under a single title but are scattered throughout the law. Consequently, the CMA and CL corporate governance provisions lack coherence and are not integrated or sufficient.

The CGR requires more stringent disclosure and transparency in corporate board annual reports than the CL. ${ }^{156}$ The CGR demands greater details about the board nomination, remuneration and audit sub-committees. The CL and CGR also give their own definitions of shareholders' rights, including the rights to vote, attend GSMs, receive dividends and bring legal action against a board member.

Both laws also give their own descriptions of board activities, such as the conduct of board meetings, remunerations of board members and conflicts of interest among board members. In the CGR, Articles 3, 5-7, 12 and 16-18 are similar to the CL Articles 66, 69-71, 73-80, 82-84, 87, 88, 93-95, 107 and 108. An example of the similarities in the laws' provisions occurs regarding conflicts of interest (CGR Article 18-B and CL Article 69). ${ }^{157}$ Where such Articles consistently agree, there is little controversy, but conflicting codes invite controversy. Where these two laws do not comply with another, there is the need to harmonise them and formulate a single code applying to all corporations whilst marking listed companies as having special disclosure obligations.

\subsection{Segregation of Duties within Board Members' Powers}

The distribution of powers among board members is proven to improve corporate governance, mostly due to increased disclosure and transparency to market participants. This distribution further eases and makes more efficient the board's supervisory role. The separation of the roles of chairman and chief executive, formerly unified in one individual, is also considered good corporate governance practice as it reduces the likelihood of conflicts of interest. ${ }^{158}$

The CL does not specifically prohibit a single individual from serving as both board chairman and CEO, ${ }^{159}$ and many corporations still follow this model. However, the CGR has taken a step towards segregating these duties by prohibiting one individual from holding the positions of chairman along with other top positions in the corporation, such as CEO, managing director and general manager. ${ }^{160}$ Therefore, the CGR has taken a positive step towards the adoption of international standards, increasing accountability and allaying suspicion of the board's involvement in corruption, malpractice and conflicts of interest. ${ }^{161}$

\subsection{Lack of Competent Professionals in the Capital Market}

The CL assumes that capital institutions employ qualified professional in the various fields. However, businesses do not always do so. Some take advantage of their autonomy to employ cheap labour with little experience. These employees then have to undergo rigorous training before they can perform their tasks. The securities commissions are expected to ensure that only qualified candidates are selected for jobs. ${ }^{162}$

\footnotetext{
${ }^{155} \mathrm{CL}$ (n 7) Article 2-5, 10.

${ }^{156}$ CGR (n 8) Articles 8-15.

${ }^{157}$ Faleh Al Kahtani, 'Current Practices of Saudi corporate governance: A case for reform' (PhD thesis, Brunel University 2013$) 93$.

158 Demirag and Solomon (n 148) 11; Alvaro Cuervo, 'Corporate Governance Mechanisms: A Plea for Less Code of Good Governance and More Market Control' (2002) 10 CG 84.

${ }^{159}$ CL (n 7) 1965.

${ }^{160}$ CGR (n 8) Article 12(d).

${ }^{161}$ Demirag and Solomon (n 148) 82.

162 T Bos and TA Fetherston, 'Capital Structure Practices on the Pacific Rim' (2003) 10(3) RIBF 53.
} 
The growth of financial institutions in Saudi Arabia has created a need for professionals that are familiar with both Islamic principles and financial products. There is a scarcity of trained professionals in the capital market who have a good understanding of Islamic and conventional finance, which some believe might hinder economic growth in Saudi Arabia. Attempts to solve this problem have fuelled the need to create educational institutions and courses that equip students with the necessary skills.

The reduction in qualified professionals in many capital market institutions has been attributed, in part, to difficulties attracting and retaining competent employees. ${ }^{163}$ Companies often employ cheap labour to minimise costs but overwork their employees, resulting in low productivity. For example, existing employees bear an extra work burden during the training of new employees, which can decrease productivity.

To solve this problem, capital markets must hire competent individuals who possess the requisite skills, are masters in their specialty and need little training. ${ }^{164}$ Doing otherwise, as the capital market is doing now, can be considered under-utilisation of human labour, which poses serious problems. It is important to note that, when human capital is not used properly, the desired outcomes may not be attained. ${ }^{165}$ In such instances, companies experience significant losses and reduced effectiveness, output and customer satisfaction.

\subsection{Implementation of Restrictions, Rules and Punishment}

The CML provides general rules covering a wide range of areas, including the stock exchange. The sanctions and penalties for violations of laws do not seem to apply to price manipulation in the stock market, ${ }^{166}$ which is a major form of market abuse. Larger traders and investors have been noted to frequently change market prices for their own advantage. Market manipulation is perhaps the easiest way for the powerful to generate wealth with minimal risk. Larger traders are well informed and, in most cases, have a say in company politics.

To reform the laws controlling the capital market and its related issues, it is necessary for the relevant bodies and authorities in Saudi Arabia to cooperate to construct rules and laws to improve the investment environment. The SSE, CMA and Ministry of Justice, along with other relevant influential departments, must attempt to create as good a market system as possible. For example, the Ministry of Justice needs to reform the law to cover violations such as market abuse and manipulation of the stock market. ${ }^{167}$

Sanctions and punishments could include freezing assets and other judicial actions performed in cooperation with the Ministry of Justice and SAMA as the banking regulator. The first priority of reform should be to protect small investors. Next are foreign institutional investors and crafting appropriate rules for their activities once they may enter the SSE. All these efforts are necessary to fully reform the Kingdom's financial system. ${ }^{168}$

Major players' power to influence stock prices hurts the public while accumulating wealth for those in power. Small traders lack the knowledge and experience to take advantage of the market so only knowledgeable traders reap maximum benefits. ${ }^{169}$ The lack of market markers has also encouraged this practice. In Saudi Arabia, market manipulation is an offence but market abuse is not regarded as a criminal offence. The CML addresses this issue, and in the wake of the February 2006 market crash, ${ }^{170}$ the CMA has developed to protect investors. However, investment activity remains low. Policy measures and regulations effected after the crash to govern the stock market prices, particularly the CML, are insufficient simply because market abuse is not regarded as a criminal offence in Saudi Arabia. ${ }^{171}$

\subsection{Lack of Disclosure of Company Information}

The CL governs disclosure and emphasises the significance of auditing and accounting reports which follow SOCPA and local accounting and auditing standards. ${ }^{172}$ Listed companies must present annual and quarterly

\footnotetext{
$163 \quad$ M Trash, 'Capital Market Institutions Lack Professionals' $<$ http://jordantimes.com/capital-market-institutions-lack-professionals> accessed 15 June 2014.

164 Uma SN, ‘A study on Training Importance for employees of their Successful Performances in Organization' (2013) 2(11) IJSR 173.

165 TM Khalid, 'Financial Audit: Comparative Study about the Responsibility of An External Auditor in the Kingdom of Saudi Arabia and the United Kingdom' (Proceedings of the Second Accounting Conference on Accounting Development, King Saud University, Riyadh, 1983).

166 Baamir (n 382) 76.

167 Baamir (n 382) 81.

168 ibid 81 .

169 ibid 78-79.

170 ibid 80 .

171 ibid 80. See also, Mohammed Alsubaie, 'Corporate Crimes committed during the phase of incorporation of companies in Saudi Arabia: legal analysis.' (PhD thesis, Unversity of Wollongong, 2012) 144.

172 WB (n 85) 30.
} 
reports with financial statements and establish audit committees. The absence of a securities regulator has made monitoring the implementation of reporting and disclosure standards more difficult. ${ }^{173}$ Regulators monitor issues related to disclosure. A study found that most Saudi firms, especially those not performing well, observe the obligatory reporting requirements but rarely disclose information voluntarily. ${ }^{174}$ Reforms to monitor compliance with auditing standards are needed.

The presence of several authorities in the Saudi capital market allows for regulatory loopholes. Saudi Arabia, along with other nations such as Japan, has yet to harmonise its accounting standards with international accounting standards. The establishment of a Saudi Securities and Exchange Commission could play the role of monitoring and overseeing the state of disclosure in Saudi Arabia. However, there is no agreement on the model of corporate governance to be established. Current policies do not encourage companies to voluntarily disclose company information. Companies disclose information only to observe the rules. ${ }^{175}$

\subsection{Government Involvement in Business Ownership and Management}

Government-linked companies have a commercial objective which is controlled by the Saudi government. The government then has a direct controlling stake and the power to make important decisions and appointments, including board members and senior management members. ${ }^{176}$ Government ownership does not necessarily translate into greater transparency. Some government-owned companies fail to comply with all the transparency and disclosure regulations. ${ }^{177}$

\section{Banking and Financial Services as Critical Sectors}

Financial institutions and the banking sector play highly pivotal roles in the adoption and establishment of corporate governance principles in the Middle East and North Africa. ${ }^{178}$ They, not capital markets, provide the primary means of business financing. Banks must improve their own disclosure and transparency policies and adhere to the twelve international standards for financial stability: ${ }^{179}$

(1) Code of Good Practices on Transparency in Monetary and Financial Policies (IMF)

(2) Special Data Dissemination Standard/General Data Dissemination System (IMF)

(3) Principles of Corporate Governance (OECD)

(4) International Standards on Auditing (IFAC)

(5) International Accounting Standards (IASB)

(6) The Forty Recommendations of the Financial Action Task Force (FATF) and Nine Special Recommendations on Financing Terrorism (FATF)

(7) Core Principles for Systemically Important Payment Systems (CPSS) and Recommendations for Securities Settlement Systems (CPSS-IOSCO)

(8) Code of Good Practices in Fiscal Transparency (IMF)

\footnotetext{
${ }^{173}$ N Malhotra and D Birks, Marketing Research: An Applied Approach (Pearson Education 2006).

${ }^{174}$ Yaseen Al-Janudi, Rashidah Abu Rahman and Normah Haji Omar, 'The level of voluntary disclosure practices among public listed companies in Saudi Arabia and United Arab Emirates: using a modified voluntary disclosure index' (2012) 9 International Journal of Disclosure and Governance 181.

${ }^{175}$ Saidi (n 327) 82-83.

${ }^{176}$ G Arnold, Essentials of Corporate Financial Management (Prentice Hall 2007).

177 The Daily Herald, 'Govt-owned companies largely ignore integrity, transparency' (2014). $<$ https://thedailyherald.com/index.php?option=com_content\&view=article\&id=50520:govt-owned-companies-largely-ignore-integrity-transp arency-\&catid=1:islands-news\&Itemid=54, accessed $>$ accessed 28 September 2014.

178 OECD, 'Advancing the Corporate Governance Agenda in the Middle East and North Africa: a survey of recent developments'. This is a draft version which will be further developed through a consultation with the participants in the MENA OECD Working Group on corporate governance in order to highlight priorities and possible recommendations for reform to improve corporate governance frameworks, promote legal changes and progress with reforms of the corporate governance of state-owned enterprises. This paper draws upon the discussions and work of the MENA-OECD Working Group on corporate governance, which is a regional forum for policy dialogue. It has built upon the MENA Regional Corporate Governance Forum, launched by MENA countries, the Global Corporate Governance Forum and the Centre for International Private Enterprise (CIPE) in 2003, with additional support from the OECD and the World Bank. The Working Group benefits from the support of CIPE and the International Finance Corporation and works closely with home grown regional and country specific initiatives and institutions (2005) 3-45. See also Basel Committee on Banking Supervision, Enhancing Bank Transparency (September 1998) 29-30<www.bis.org/publ/bcbs41.htm> accessed 28 September 2014.

179 OECD (n 87) 9.
} 
(9) Objectives and Principles of Securities Regulation (IOSCO)

(10) Insurance Core Principles (IAIS)

(11) Principles and Guidelines for Effective Insolvency and Creditor Rights Systems (World Bank)

(12) Core Principles for Effective Banking Supervision (BCBS)

Many countries apply international accounting standards, and this aids potential investors from other countries. These standards have been harmonised among many countries, which has eliminated the obstacle of different rules and standards to foreign and even domestic investments. The lack of such standards hinders investors and economic growth, but with the implementation of an international standard countries such as Saudi Arabia reduced the difficulty of its national standards, attracted investors and supported general economic growth. However, this is only being adopted in the bank and insurance sectors. ${ }^{180}$

Saudi Arabia's efforts to adopt the international standards spurred a number of neighbouring countries to do so as well in order to increase economic investment in their countries and diversify their economic activities and resources. These steps will contribute to an improved economy and long-term development. This patent illustrates that disclosure of financial statements is vital for both investors and the players in a financial institution in order to identify appropriate strategies for whatever business situations arise for the investor. Disclosure and transparency gives clients access to information that reveals the true status of each financial company. The science of accounting has become an urgent necessity for JSCs where several people make decisions, unlike older firms managed directly by the owner. ${ }^{181}$

Capital markets should receive high priority in reform in order to nurture economic growth and national development. ${ }^{182}$ The CMA helps govern activities that do so, especially in foreign exchanges. These activities increase trade between countries, which in the long run improves the country's economy. ${ }^{183}$ Financial institutions are the key players in this field and, therefore, should implement and develop sound corporate governance to offer better, more responsive services.

\section{Enforcing Disclosure: Role of Authority}

The CMA is an independent body established to deal with corporate governance. ${ }^{184}$ It is responsible for drafting and enforcing rules and guidelines that achieve sound corporate governance and for enforcing disclosure by organisations. Put briefly, corporate governance was established to guide and manage all business internal and external to companies. ${ }^{185}$ This effort established a precise system which defines the responsibilities and duties of companies' board of directors and executive management while protecting the rights of shareholders and stakeholders of all sizes. In the CMA's 2008 annual report, the agency states its plans to create an independent department to monitor listed companies' compliance with corporate governance regulations. ${ }^{186}$ According to the CMA's 2009 annual report, six companies failed that year to release their board of directors' reports for the preceding year in accordance with the CGR requirements compared to 11 companies in 2008.

As mentioned earlier, the CMA reserves the right to compel any organisation or company to make the required disclosures. ${ }^{187}$ The CMA also governs the stock exchange and share prices of listed companies. The SSE works closely with the CMA to monitor the financial activities of most major companies in Saudi Arabia. The agencies aim to increase the credibility of the SSE and listed companies by enforcing clear, transparent regulations for organisations. ${ }^{188}$

The CMA also collaborates with the SAMA in raising awareness of the importance of corporate governance among companies, shareholders and stakeholders, and encouraging the development of director training programmes to build a cadre of qualified directors. The enhancement of corporate governance practices remains instrumental to better protect investors, improve company oversight and increase confidence in capital markets.

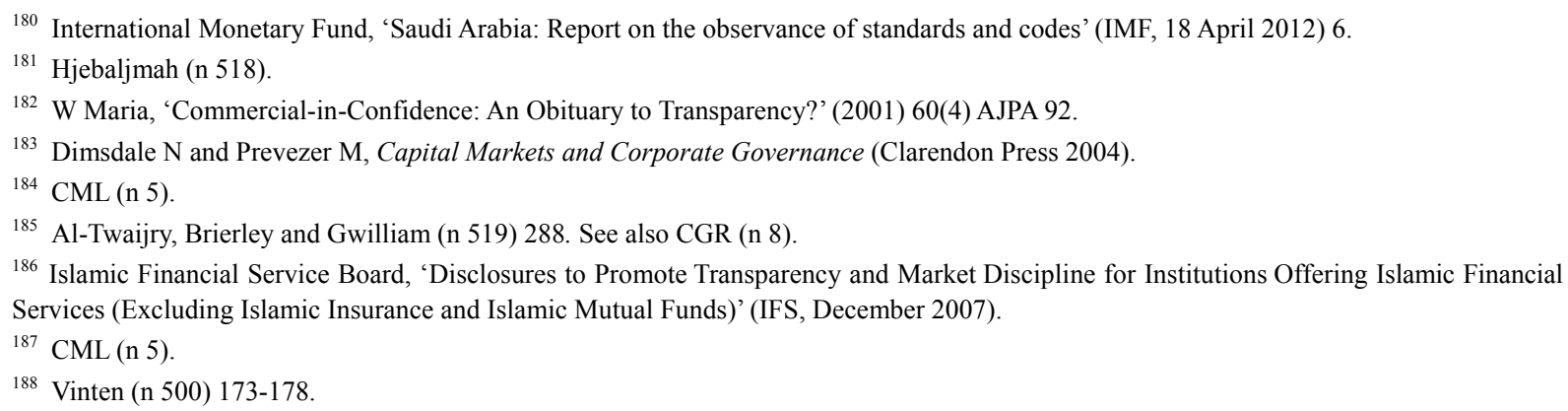


These authorities play a major role in the implementation of reforms and in overseeing the adoption of corporate governance, which ultimately attracts more investors, spurs development and grows the economy. ${ }^{189}$

\section{Amending and Reforming Commercial Regulations}

Commercial regulations deal mainly with restrictions and laws at a regional level. For example, under the 1962 Commercial Agency Regulations, investors who are not Saudi nationals are not permitted to act in any way as commercial agents in Saudi Arabia. Moreover, all commercial agents must be registered with the Ministry of Commerce. In 1981, the Ministry adopted implementation rules stipulating that Saudi distributors were responsible for registering the foreign investors they represented.

It is recommended that an independent body governs the establishment and implementation of laws and regulations on corporate governance principles. Such bodies include the CMA and the IMF. These draft, adopt and amend disclosure and transparency and corporate governance rules and regulations for financial sectors and other organisations.

Saudi Arabia has no single, available, complete code of corporate governance, even though the CMA has issued a code which companies are recommended to follow. However, enforcement of this code not strict. ${ }^{190}$ It has been proven that regions and countries which implement quality corporate and public governance principles obtain improved market activities and development. This benefit is mainly associated with economic policy reforms, particularly in privatisation, trade, and investment policies. This has reduced the cost of doing business, increased economic efficiency and eliminated barriers and obstacles to diversified export growth and foreign direct investment. ${ }^{191}$

\section{Guidance from Foreign Experience and International Organisations}

Foreign experiences and assistance from international organisations that have adopted a corporate governance system are very helpful in resolving any doubts a company might have before implementing disclosure and transparency. These examples demonstrate the benefits of corporate governance, such as more investors and higher quality standards and development in the long run.

Countries with substantial experience in corporate governance can provide support to stakeholders in a developing market, such as the SSE and players in banking and financial institutions. This assistance reinforces organisational ethics of disclosure, accountability, responsibility and transparency. These countries could help Saudi Arabia draft disclosure laws and form agencies to monitor the implementation of reforms. ${ }^{192}$

Studying previous examples of countries which have implemented corporate disclosures rules can help in the enforcement of workable regulations in developing countries. ${ }^{193}$ Saudi Arabia could borrow ideas from developed countries, such as the United States, to examine the differences in investor capacity and development between companies and organisations with and without sound corporate governance. In this context, the challenge is to transform international standards and regulations into national and regional regulations. This effort requires complete commitment from both the responsible authorities and the region attempting to assimilate corporate governance principles. Successful incorporation of these standards into a regional institutional and legal framework while modernising and reforming the latter to create the infrastructure for effective corporate governance requires keeping in mind the specific reason for implementation, including objectivity, commitment, and transparency. ${ }^{194}$ Doing so makes it easier to implement a national corporate governance system that bears fruits.

\section{Transparent and Accountable Regulators and State Officials}

Regulators are the authorities responsible for enforcing the restrictions and rules that govern the adoption of corporate governance principles. State officials should be transparent and accountable, setting examples for the

\footnotetext{
189 WB (n 85) 9.

${ }^{190}$ In its annual report dated 2008, the CMA stated that it would create an independent department to monitor compliance of listed companies with the corporate governance regulations. According to the CMA annual report of 2009, 6 companies failed to comply in 2009 with disclosure in their board of directors' reports for the preceding year, in accordance with the requirements of the "Corporate Governance Regulations", as compared with $11 \quad$ companies $\quad$ in $2008 . \quad$ See $<$ http://www.tamimi.com/en/magazine/law-update/section-7/april-6/corporate-governance.html\#sthash.2LIkZE1P.dpuf $>$ accessed 12 September 2012.

${ }^{191}$ D Bence, K Hapeshi, and R Hussey, ‘Examining Investment Information Sources for Sophisticated Investors' (1995) $26(1)$ ABR 1.

192 Saidi (n 327) 13.

193 ibid.

${ }^{194}$ P Wong, 'Challenges and Successes Implementing International Standards: Achieving Convergence to IFRSs and ISAs' (IFAC, 2004$) 4$.
} 
stakeholders that are expected to adopt the corporate governance system. Such officials will also set an example of transparency for government-owned companies, some of which, as mentioned, fail to comply with all disclosure regulations.

In cases where the personnel spreading the concept of corporate governance are not accountable and responsible themselves, it will be a difficult task for others to adopt the same concept. However, adoption is easier when the regulators and state officials themselves have developed sound corporate governance.

Corporate governance entails full disclosure of information that is relevant to clients and investors. Therefore, while enforcing corporate governance regulators need to be forthright and transparent about what kind of information the organisation should disclose and to what extent. Disclosure and transparency entail a flow of timely, verifiable, reliable, economically accountable and political information about policies and outcomes involved in certain decisions and events. This information helps clients and investors to make decisions based on expectations in the information provided. This disclosure system entails a public policy framework to identify information important and relevant in the market and political processes, and to ensure that quality information is accessible to the entire public instead of a privileged few. ${ }^{195}$

A vital characteristic of transparency and disclosure is the importance of information as a public good. Therefore, information should be a matter of concern for the public and government officials. These officials should set public disclosure standards and regulations and ensure that companies - whether private or public - apply the recommended international accounting standards and accordingly disclose information and reports. ${ }^{196}$ Better quality information available in the market increases resource utilisation and the economic efficiency of workers, consumers and producers.

Transparency and information disclosure is essential in financial fields to ensure that capital and financial resources are allocated where they are useful and most productive. The availability and dissemination of quality, timely information about companies depends on accounting practices and standards, as well as on good corporate governance. In systems with poor corporate governance, capital might be mismanaged and financial resources may not be put to their best uses. ${ }^{197}$

The Implementation and Regulatory Committee has two major roles in establishing corporate governance in Saudi Arabia. Its first function is to help prepare all necessary documents and information. Its second function is to work closely with the media and ensure that these documents and information reach the responsible stakeholders and audiences, thus raising awareness of corporate governance. ${ }^{198}$ The Committee plans and runs forums and training in corporate governance principles. These duties of state officials and the regulatory body need deep transparency and accountability.

A corporate governance action plan and corporate sector reform programmes require complete information and detailed assessments in order to prioritise actions and formulate remedial government policies for dealing with hindrances and obstacles in the process. The development of the action plan involves full accountability and responsibility; thus, the regulatory body and state officials involved should uphold high standards of corporate governance and general information sharing/disclosure. ${ }^{199}$

A combination of these solutions is the ideal means to achieve a sound system of corporate governance. ${ }^{200}$ To encourage transparency in the Saudi capital market and develop corporate governance standards, the CMA, in decision No 1-20-2008, dated 19 May 2008, certified a modification to Clause (a) of Article 18 of the CGR: 'A Board member shall not, without prior authorisation from the General Assembly, which must be renewed each year, have any interest (whether directly or indirectly) in the company's business and contracts. The activities to be performed through general bidding shall constitute an exception where a Board member is the best bidder' ${ }^{201}$ These steps will help to protect the rights, investments and reserves of the company, investors and

\footnotetext{
195 Saidi (n 327) 66-67.

196 ibid.

197 Saidi (n 327).

${ }^{198}$ Cordella T and Yeyati EL, 'Public Disclosure and Bank Failures' (1998) 45(1) IMF Staff Papers 110.

${ }^{199}$ Chaganti R and Damanpour F, 'Institutional Ownership, Capital Structure, and Firm Performance' (1999) 12(7) Strategic Management Journal 479.

${ }^{200}$ Fairbanks, Plowman and Rawlins (n 81) 22-37.

${ }^{201}$ G20, 'Globalization: The Role of Institution Building in the Financial Sector-Report to Ministers and Central Bank Governors' (2002) $<$ http://www.g7.utoronto.ca/g20/20031026_fr_mex.pdf> accessed 9 May 2012.
} 
shareholders. $^{202}$ Nevertheless, this improvement is only a small step, and a complete overhaul of the system is needed to develop the corporate sector and make sure there is sufficient corporate governance in Saudi Arabia. ${ }^{203}$

\section{Summary}

This articel has dealt with the issues that involve corporate transparency in the Saudi capital market. Topics discussed included the Saudi approach to disclosure and transparency, CML disclosure provisions and regulations addressing market abuses, such as price manipulation, irregular trading and name and shame. The regulatory response to the market crash of February 2006 has been described, followed by the degree and manner of the country's compliance with the OECD Principles of Corporate Governance. This compliance includes investor protection, disclosure and enforcement. Shortcomings in the legal framework, such as a lack of separate regulation, scarcity of competent staff in the capital market and cultural and environmental factors, have been explained. Finally, the chapter describes the types of reform and necessary conditions for the effective implementation of the principles of corporate governance, particularly the tenets of disclosure and transparency. A discussion has also been provided on the manner that it is necessary to act should poor corporate governance occur, namely, the failures of disclosure, insider trading and the processes involved in addressing the anomalies that ensue. Naming and shaming is considered an ideal option in the Islamic world as religion is intrinsic to people's daily lives - going against the moral codes of corporate governance can be equated to going against religion and thus hurting people's confidence in the system.

Transparency and the disclosure of information are determinants of development and economic growth and, without them, economic progress cannot be sustained. The robustness of activity in a market economy depends to a great extent on complete, timely and accurate information which determines resource allocation, improves the efficiency of market activity and increases production, which drives the economy. The preceding chapters, particularly the discussion of scandals and disclosure, demonstrated that SSE listed companies still fall short of the standard of transparency desirable for an efficient market. In part, this is because Saudi Arabia is an emerging economy and Saudi corporate culture is still assimilating the corporate governance culture. The behaviours of individuals involved, such as board members, executives and investors, are conditioned by the customary Saudi social relations and have yet to be adjusted to the constraints of abiding by international standards which are different to accustomed behaviour. The Saudi approach to disclosure and transparency has also been examined, particularly the board annual report.

\footnotetext{
${ }^{202}$ Hermalin B and Weisbach M, 'Boards of Directors as an Endogenously Determined Institution: A survey of the Economic Literature' (2003) 3(1) FRBNY EPR 7.

203 Fadi Dahar, 'Corporate Governance'

$<$ http://www.tamimi.com/en/magazine/law-update/section-7/april-6/corporate-governance.html\#sthash.2LIkZE1P.dpu> accessed 26 September 2014. There have been various developments recently in Saudi Arabia towards increasing the effectiveness of the Corporate Governance framework.
} 